\title{
The effectiveness of absorption heat pumps application for the increase of economic efficiency of CHP operation
}

\author{
Dmitriy S. Luzhkovoy ${ }^{1 *}$, Olga Yu. Romashova ${ }^{1}$, Aleksandr A. Tubolev ${ }^{1}$, Yuriy V. \\ Kobenko ${ }^{1}$, Elena S. Riabova ${ }^{2}$ \\ ${ }^{1}$ National Research Tomsk Polytechnic University, 634050 Tomsk, Russia \\ ${ }^{2}$ Samara State Social-Pedagogical University, 443099 Samara, Russia
}

\begin{abstract}
The article deals with a comparative analysis of CHP operational efficiency in various working modes before and after the absorption heat pumps installation. The calculation was performed using a mathematical model of the extraction turbine PT- 80/100-130/13. Absorption heat pumps of LLC "OKB Teplosibmash" were used as AHP models for the analysis. The most effective way of absorption lithiumbromide heat pumps application as a part of the turbine PT-80/100-130/13 turned out to be their usage in a heat-producing mode during a non-heating season with a load of hot water supply. For this mode the dependence of the turbine heat efficiency on the heat load of the external consumer at a given throttle flow was analyzed.
\end{abstract}

\section{Introduction}

Efficiency improvement of energy supply application tends to be a worldwide problem as the demand for them, which is increasing every year, inevitably leads to the difficulties of economic, environmental and technical nature. For the Russian energy system, which is dominated by cogeneration, the problem of increasing the efficiency of existing combined heat and power stations is particularly important.

One of the most promising technologies for CHP implementation is to convert low-heat into high-grade heat using absorption heat pumps (AHP).

The positive effect of the heat pumps implementation in CHP operation depends on its working mode. When operating in the condensing mode AHP can be used for fuel-flow condensate heating, and in heat-extraction mode it can be used for heating the main condensate, delivery water, raw water used for the station needs $[4,5]$ after chemical cleaning (including heat supply makeup).

The effect of the fuel economy while using AHP at CHP becomes evident if at a given throttle flow the operation performed by the whole stem flow of the turbine is increased. It becomes possible in two cases:

\footnotetext{
*Corresponding author: ds18@tpu.ru
} 
- $\quad$ if underproduction by vapor system that is selected for the heat pump system will be less than the extra work that is gained as a result of steam consumption reduction for the regenerative, line-operated or other (for example, plantwide) heat exchanges.

- $\quad$ if by means of cooling circulating water it becomes possible to reduce the pressure in the condenser and thus, increase the available heat drop.

The first case corresponds to the turbine operation when the steam of a higher capacity than is required by heat-exchange conditions is supplied to one of the heat exchangers. Most of industrial-heating CHP have plant heat exchangers (the heaters of chemically demineralized, chemically purified, raw water, atmospheric deaerators) that get the steam from the plant collector which is powered through PRDS from the industrial turbine extraction.

The aim of the research is to carry out a comparative analysis of the calculation data of absorption heat pumps inclusion into the scheme of the extraction turbine of PT-type in the context of its operation modes.

\section{Features of the analyzed system}

As a model, which was used for analyzing the efficiency of heat pumps integration, turbine PT-80/100-130/13 was taken. Its basic diagram is presented in [1]. Initial data for turbine operation modes were taken from [2].The models of absorption heat pumps were AHP of the company of LLC "OKB Teplosibmash" [3].

For the analysis the characteristic turbine operation modes with controlled heating and industrial extraction were chosen: heat-producing mode from a heat graph with a rated capacity load of regulated extraction, condensing mode, heat-producing mode with a plant heat load of DHW that is provided by P-extraction.

In the condensing mode the full-flow condensate before the first LPS was heated by AHP, in the heating mode the same was done with the raw water after chemical cleaning behind the plant heater. Circulating water was cooled in all cases.

Figures 1 and 2 show the calculation model of chemically purified water preparation for the heat supply makeup before and after the introduction of heat pumps.

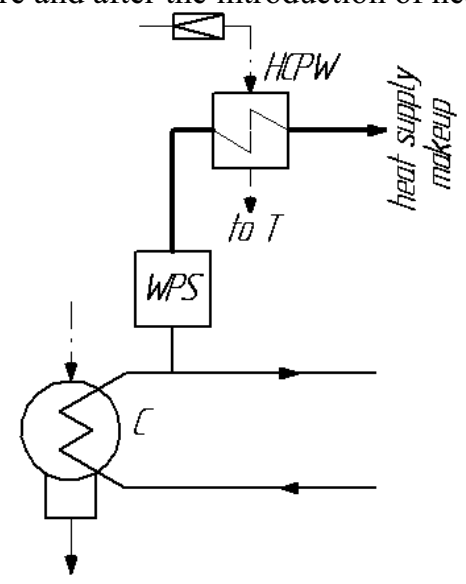

Fig. 1.The model of makeup water preparation before the introduction of heat pumps where $\mathrm{C}-$ condenser; WPS - water purification section; HCPW - the heater of chemically purified water; T turbine 


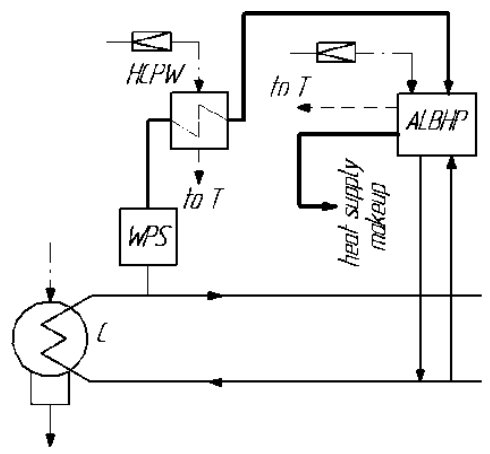

Fig. 2. The model of makeup water preparation after the introduction of heat pumps where ALBHP absorption lithium-bromide heat pumps; the remaining symbols are the same as in Fig.1

\section{Calculation results}

Tab. 1 and Fig. 1 and 2 show the calculation data of the turbine in the heat extraction mode with the heat release for the heat supply makeup during the summer period at CHP. The main steam rate is set to $\left(\mathrm{G}_{0}=80 \mathrm{~kg} / \mathrm{sec}\right)$.

Table 1. The comparison of calculation results of the turbine PT-80/100-130/13 in the heat extraction mode at various heat supply makeup values.

\begin{tabular}{|c|c|c|c|c|c|c|}
\hline \multirow[b]{2}{*}{ Index } & \multicolumn{2}{|c|}{ makeup $125 \mathrm{~kg} / \mathrm{sec}$} & \multicolumn{2}{|c|}{ makeup $250 \mathrm{~kg} / \mathrm{sec}$} & \multicolumn{2}{|c|}{ makeup $500 \mathrm{~kg} / \mathrm{sec}$} \\
\hline & $\begin{array}{l}\text { without } \\
\text { ALBHP }\end{array}$ & $\begin{array}{l}\text { with } \\
\text { ALBHP }\end{array}$ & $\begin{array}{l}\text { without } \\
\text { ALBHP }\end{array}$ & $\begin{array}{c}\text { with } \\
\text { ALBHP }\end{array}$ & $\begin{array}{l}\text { without } \\
\text { ALBHP }\end{array}$ & $\begin{array}{c}\text { with } \\
\text { ALBHP }\end{array}$ \\
\hline $\begin{array}{l}\text { Steam consumption for } \\
\text { the turbine, } \mathrm{kg} / \mathrm{sec}\end{array}$ & \multicolumn{6}{|c|}{80} \\
\hline $\begin{array}{c}\text { Generated electrical } \\
\text { power, MW }\end{array}$ & 70.916 & 72.423 & 66.752 & 68.491 & 53.29 & 59.794 \\
\hline $\begin{array}{l}\text { Steam consumption in the } \\
\text { cond., } \mathrm{kg} / \mathrm{sec}\end{array}$ & 48.61 & 50.54 & 40.65 & 44.76 & 22.43 & 30.08 \\
\hline Pressure in the cond., $\mathrm{kPa}$ & 9.2 & 9.1 & 8.4 & 8.3 & 6.7 & 6.5 \\
\hline $\begin{array}{c}\text { Temperature of circ. } \\
\text { water at the condenser } \\
\text { inlet, }{ }^{\circ} \mathrm{C}\end{array}$ & 20 & 19.3 & 20 & 18.9 & 20 & 17.7 \\
\hline $\begin{array}{l}\text { Temperature of circ. } \\
\text { water at the condenser } \\
\text { inlet, }{ }^{\circ} \mathrm{C}\end{array}$ & 31.1 & 30.8 & 29.3 & 29.1 & 25.1 & 24.5 \\
\hline $\begin{array}{l}\text { Circ. water consumption, } \\
\mathrm{kg} / \mathrm{sec}\end{array}$ & \multicolumn{6}{|c|}{2222} \\
\hline $\begin{array}{c}\text { Steam consumption from } \\
\text { P-extraction at HCPW, } \\
\mathrm{kg} / \mathrm{sec}\end{array}$ & 7.6 & 1.72 & 15.91 & 4.06 & 35.1 & 11.57 \\
\hline $\begin{array}{c}\text { Total steam consumption } \\
\text { from P-extraction at } \\
\text { HCPW and ALBHP, } \\
\mathrm{kg} / \mathrm{sec} \\
\end{array}$ & 7.6 & 5.92 & 15.91 & 12.31 & 35.1 & 28.07 \\
\hline $\begin{array}{l}\text { Heat transferred to } \\
\text { makeup water, MW }\end{array}$ & 26.19 & 26.19 & 52.4 & 52.4 & 104.7 & 104.7 \\
\hline $\begin{array}{l}\text { Temperature of heat } \\
\text { supply makeup, }{ }^{\circ} \mathrm{C}\end{array}$ & \multicolumn{6}{|c|}{70} \\
\hline $\begin{array}{l}\text { Heat taken away from the } \\
\text { cold supply, MW }\end{array}$ & - & 5.72 & - & 11.79 & - & 23.57 \\
\hline
\end{tabular}




\begin{tabular}{|c|c|c|c|c|c|c|}
\hline $\begin{array}{c}\text { Electr. efficiency factor } \\
\text { of the gross bucket }\end{array}$ & 0.3956 & 0.404 & 0.4296 & 0.4505 & 0.5292 & 0.5936 \\
\hline $\begin{array}{c}\text { Specific reference fuel } \\
\text { consumption at el. energy } \\
\text { efficiency b, gr.ref.fuel / } \\
\mathrm{kW} \text { *h }\end{array}$ & 388.1 & 380.1 & 357.5 & 340.8 & 290.2 & 258.7 \\
\hline
\end{tabular}

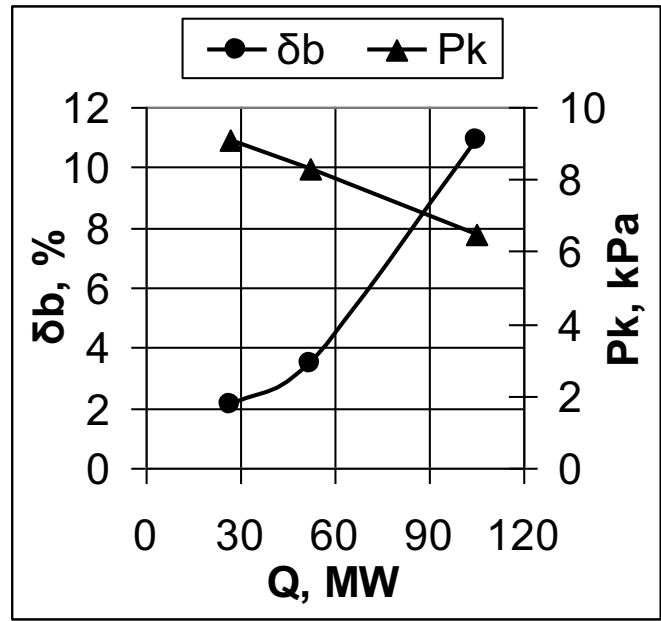

Fig. 3. Dependence of the relative change in the fuel economy on the turbine PT-80/100-130/13 and the pressure in the condenser on the heat load of the external consumer $\left(\mathrm{G}_{0}=80 \mathrm{~kg} / \mathrm{sec}\right)$

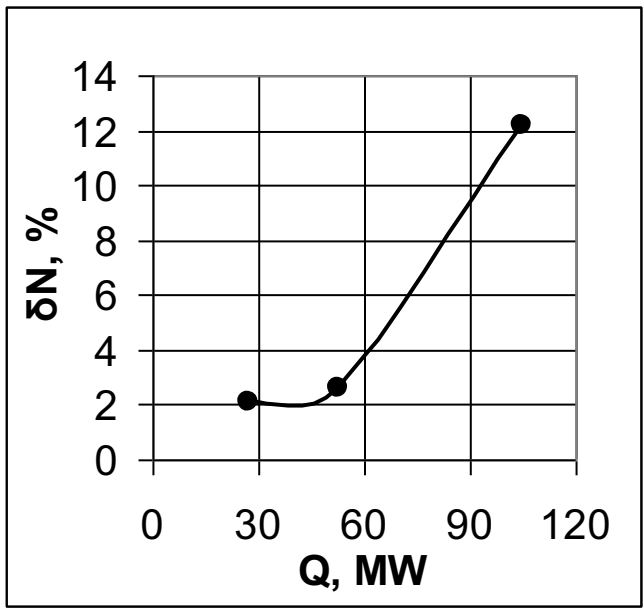

Fig. 4. Dependence of the relative gain of the electric power generated by the turbine PT- 80/100$130 / 13$ on the heat load of the external consumer $\left(G_{0}=80 \mathrm{~kg} / \mathrm{sec}\right)$

\section{Conclusions}

1. The application of absorption heat pumps in the condensing mode does not provide an appreciable effect of fuel economy because a positive result from the pressure reduction in the condenser and, consequently, an increasing turbine heat drop are balanced by a negative result from the steam replacement that is necessary for regeneration. However, the application of AHP reduces the pressure in the condenser by cooling the circulating water at the condenser inlet in such a case when it is 
necessary to limit the steam consumption in the turbine to maintain the required vacuum in the condenser (for example, summer limitation of electricity production).

2. The application of AHP in the heating mode on the thermal graphics with rated capacity load of regulated extractions does not lead to the reduction of the specific fuel consumption. In this case, it is not possible to use the pressure reduction effect in the condenser with the help of AHP, as during the cold season the cooling water temperature is low, and there are not any problems with the creation of vacuum in the condenser. Thus, it does not make economic sense to reduce the pressure using AHP.

3. The most effective method of using AHP as part of the turbine PT-80/100-130/13 is its application in the heating mode during a non-heating season with a load of hotwater supply. In this case it is possible to get a positive effect both from the condenser pressure decrease and the steam flow reduction to heat the makeup water.

4. The influence of external heat load $\mathrm{Q}_{\mathrm{m}}$ on the efficiency of heat pumps application was analyzed. The increase of $\mathrm{Q}_{\mathrm{m}}$ from $26 \mathrm{MW}$ to $105 \mathrm{MW}$ with the steam flow on the turbine $\mathrm{G}_{0}=80 \mathrm{~kg} / \mathrm{sec}$ results in the reduction of specific reference fuel consumption from $2.1 \%$ to $10.9 \%$ (fig. 3 ).

5. The introduction of the absorption heat pumps into the heat-extraction turbine turns out to be an effective means of improving the efficiency of CHP. However, in order to get the maximum benefit from it, it is important to consider the operation modes of the turbine that determine the efficiency of the heat pump system.

\section{References}

1. E.A. Bojko, K.V. Bazhenov, P.A. Grachev, Thermal power stations (steam turbine power stations of CHP): (IPC KGTU, Krasnojarsk, 2006)

2. S.V. Tsanev, I.N. Tambieva Thermal diagram and cogeneration values of CHP and APS: (MEI, 1987)

3. The official website of LLC "OKB Teplosibmash" [Electronic resource]

4. B.V. Lukutin, E.B. Shandarova, A.F. Makarova, D.L. Matukhin, I.L. Fuks, IOP Conf. Ser. Mater. Sci. Eng. 124, 012070 (2016)

5. B.V. Lukutin, E.B. Shandarova, I.O. Muravlev, D.L. Matukhin, A.F. Makarova, International Conference on Mechanical Engineering, Automation and Control Systems (MEACS), 1 (2015) 